УДК 519.816

DOI https://doi.org/10.32838/2663-5941/2021.4/11

\title{
Кандиба I.O.
}

Чорноморський національний університет імені Петра Могили

\section{БАГАТОКРИТЕРІАЛЬНИЙ ВИБІР КРАЩОГО СЦЕНАРІЮ ВСТУПНОЇ КАМПАНІЇ ЗАКЛАДУ ВИЩОЇ ОСВІТИ}

У статті наведено аналіз сучасних методів багатокритеріальної оптимізації: оптимальності за Парето, методу послідовних поступок, методу головного критерію та методу лінійної згортки. Досліджено можливість реалізації зазначених методів багатокритеріальної оптимізації в інформаиійній системі генерації сиенаріїв на основі графових структур. Запропоновано предметно-орієнтовану мову для опису иільових функиій. Зроблена пропозиція граматики для запису цільових функцій під час застосування оптимальності за Парето. Зображено абстрактні синтаксичні дерева зазначених граматик. Згенеровано лексичні й синтаксичні аналізатори для обробки вхідного рядка з описом функиій оптимізаиії. Представлено алгоритм знаходження множини Парето оптимальних рімень із множини згенерованих сценаріїв. Описано основний принцип та алгоритм реалізації методу послідовних поступок під час вибору кращих за певними критеріями або їх сукупністю сиенаріїв серед множини згенерованих. Представлено особливості реалізації методу головного критерію в інформачійній системі генерачї множини сиенаріїв. Наведено граматику для обробки вхідного рядка, що містить функиію оптимізації та обмеження методу головного критерію. Зображено опис методу лінійної згортки й алгоритм реалізаиії для інформаційної системи генерації сценаріїв на основі графових структур. Запропоновано граматику правил для вхідного рядка реалізаиії методу лінійної згортки. Сформовано програмну реалізацію всіх досліджених методів багатокритеріальної оптимізації. Наведено опис інтерфейсу, що дозволяє особі, що приймає рімення (ОПР), робити вибір одного з реалізованих методів багатокритеріальної оптимізації з можливістю опису функиій оптимізації та перегляду кращих сиенаріїв. Як приклад застосування розроблених засобів обрано сиенарний аналіз проведення вступної кампанії закладу вищої освіти (3ВО) на основі реалізованих методів багатокритеріальної оптимізації. Визначено подальші шляхи розвитку розробленої інформачійної технології.

Ключові слова: багатокритеріальна оптимізачія, метод послідовних поступок, метод лінійної згортки, метод головного критерію, оптимальність за Парето, предметно-орієнтована мова програмування.

Постановка проблеми. Задачі передбачення завжди ведуть до етапу прийняття рішень $[1$, c. 24]. Це твердження вірне для задачі передбачення вступної кампанії закладу вищої освіти (далі - 3ВО), що можна розв'язувати методами сценарного аналізу.

Визначивши множину можливих подій вступної кампанії та сформувавши взаємозв'язки між цими діями можливо застосувати метод генерації сценаріїв на основі графової моделі [2, с. 152]. Результатом вищеописаних дій є множина сценаріїв, що являють собою альтернативні варіанти проведення вступної кампанії. Кожен з генерованих сценаріїв має набір характеристик (критеріїв), при цьому вибір оптимального сценарію проведення вступної кампанії являє собою задачу багатокритеріальної оптимізації.

Необхідно визначити сценарій, при якому буде, під кутом зору оптимізації набору критеріїв в цілому, узгоджено декілька конфліктних цільових функцій: мінімізовано витрати на проведення вступної кампанії, максимізовано середній бал абітурієнта, мінімізовано витрачений час викладачів залучених до вступної кампанії та інше. Наведені вимоги обумовлюють актуальність розв'язання задачі багатокритеріального вибору кращого сценарію серед генерованих спеціальними мовними засобами, в тому числі для вступної кампанії ЗВО.

Аналіз останніх досліджень i публікацій. Незважаючи на метод, за яким було генеровано множину сценаріїв для, вибору найбільш вдалого сценарію необхідне використання методів підтримки прийняття рішень при багатокритеріальної оптимізації [3, с. 91].

У роботі [4, с. 568] описане застосування методу аналізу ієрархій (далі - MAI) для оцінки критеріїв, за якими порівнюються потенційні постачальники та визначення оптимальної альтернативи. Автори описують послідовність реалізації MAI для альтернатив, що задані користувачем в ручну. У роботі недостатньо повний опис можливості застосування MAI для множини згенерованих альтернатив. 
Робота [5, с. 27] містить опис та розв'язання задачі багатокритеріальної оптимізації для галузі вантажоперевезень. Досліджено оптимальність за Парето та актуальність ії застосування у транспортних задачах. Однак, у роботі не запропоновано універсальних програмних реалізацій цього методу багатокритеріальної оптимізації.

Застосування методу послідовних поступок $€$ одним $з$ розповсюджених при розв'язання задач багатокритеріальної оптимізації, що описано в робі [6, с. 143]. У ній представлено можливість застосування методу послідовних поступок для визначення раціонального сценарію підвищення рентабельності виробництва малого підприємства. Наведено опис математичного апарату застосування методу послідовних поступок, але недостатньою увагу приділено його програмній реалізації.

У роботі $[7$, с. 26] задачу багатокритеріальної оптимізації для вибору джерела альтернативної енергії пропонується розв'язувати на основі методу лінійної згортки. Робота містить опис математичного апарату для реалізації методу лінійної згортки, але не запропоновано програмних засобів реалізації цього методу.

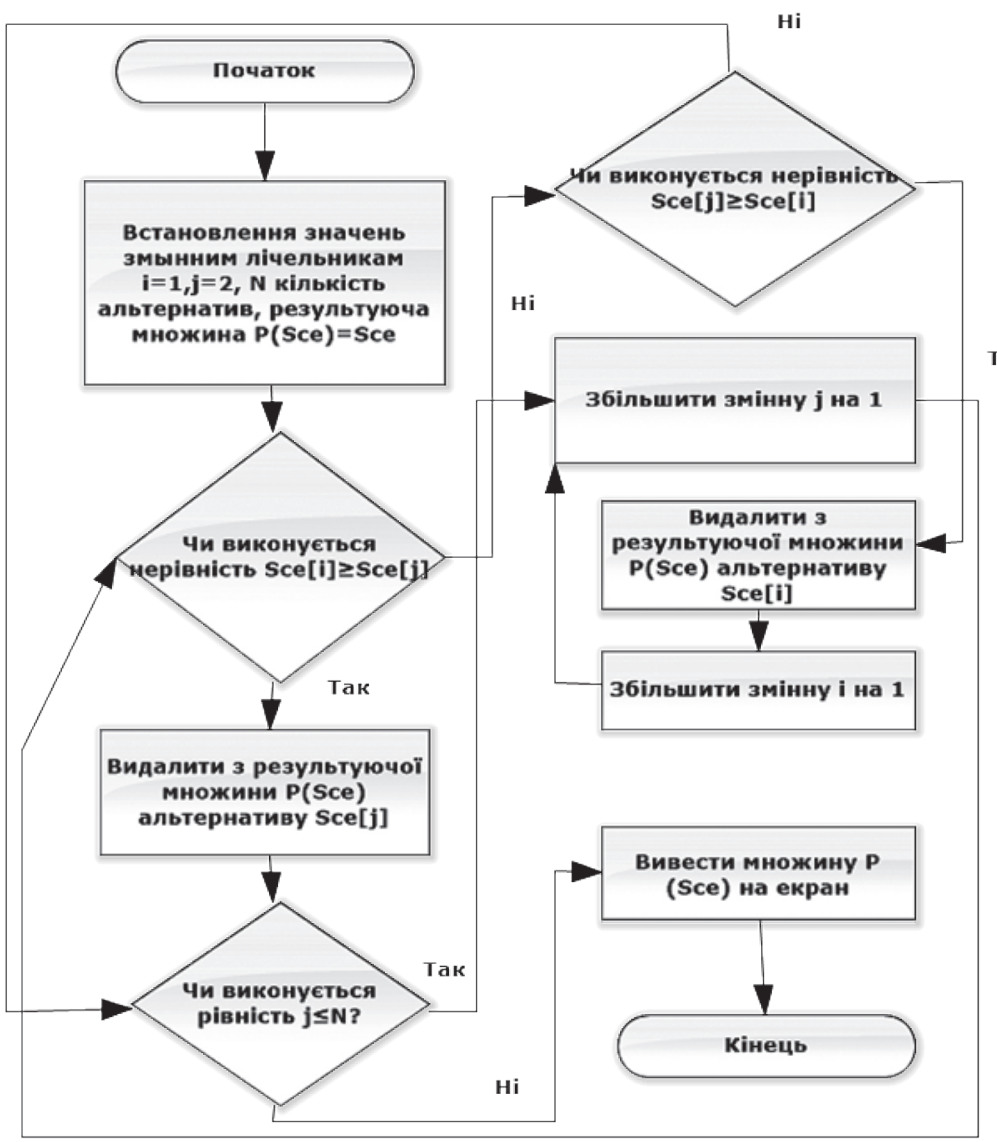

Рис. 1. Блок-схема алгоритму знаходження множини Парето оптимальних рішень
У роботі [7, с. 25] описується можливість застосування методу головного критерію для розв'язання задачі багатокритеріальної оптимізації, але для цього методу також не запропоновано програмних засобів реалізації.

Виконаний аналіз показав, що питання багатокритеріальної оптимізації актуально для багатьох галузей діяльності, але питання програмних засобів реалізація методів багатокритеріальної оптимізації потребують подальших досліджень, зокрема щодо розроблення інформаційних технологій із застосуванням мовних засобів моделювання предметних галузей та генерації сценаріїв на їх основі і багатокритеріальної оптимізації.

Постановка завдання. Метою дослідження $€$ розробка інформаційної технології для вибору кращого сценарію 3 множини згенерованих. Створення відповідної інформаційної системи дозволить обирати серед множини згенерованих найбільш ефективний сценарій, зокрема при проведенні вступної кампанії університету на основі багатокритеріальної оптимізації. Для досягнення зазначеної мети поставлені такі задачі:

- дослідження методів багатокритеріальної оптимізації, що можливо застосувати для вибору найбільш оптимального сценарію проведення вступної кампанії;

розробка предметно-орієнтованої мови програмування для опису цільових функцій для множини критеріїв згенерованої на основі графових структур;

реалізація методів багатокритеріальної оптимізації для визначення найбільш оптимального сценарію серед згенерованих.

Виклад основного матеріалу дослідження. Генерація сценаріїв може здійснюватися на основі використання комбінацій різних груп методів [3, с. 91]:

- якісні методи генерації сценаріїв (метод Делфі, метод мозкового штурму, метод аналогій, морфологічний аналіз та ін.);

графові методи генерації сценаріїв (дерево подій, дерево ймовірностей, дерево відмов).

Кожна група методів має власні особливості, але не залежно від них на виході етапу генерації має бути множина сценаріїв. Кожен сценарій має набір характеристик, на які спи- 
рається особа, що приймає рішення (далі- ОПР) під час вибору оптимального.

Розв'язання задачі багатокритеріального вибору або задачі багатокритеріальної оптимізації може бути здійснене за допомогою різних методів. Одним із найвідоміших методів розв'язання задачі багатокритеріальної оптимізації $є$ оптимальність за Парето [5 с. 27]. Основна ідея оптимальності за Парето полягає в існуванні альтернатив, жодну характеристику з яких не можливо покращити без погіршення іншої. Тобто математично множину Парето оптимальних альтернатив можна представити таким чином [8, с. 13]:

$\mathrm{P}(\mathrm{Sce})=\left\{\mathrm{Sce}^{*} \in \mathrm{Sce} \mid\right.$ не існує Sce $\in$ Sce,

$$
\text { для якої Sce' } \left.>\mathrm{Sce}^{*}\right\} \text {, }
$$

де Sce - множина альтернатив.

Вибір оптимальних рішень здійснюється шляхом максимізації чи мінімізації певного критерію $[6$, c. 143$]$.

Алгоритм знаходження множини Парето оптимальних рішень описано у роботі $[8$, с. 13]. Отже можливо представити алгоритм у вигляді блок схеми, зображеної на рис. 1.

При використанні інформаційної системи для генерації множини сценаріїв кожен 3 них можна представити кортежем, що у якості елементів містить характеристики сценарію, а множину сценаріїв у вигляді масиву [2, с. 154]. В інтерфейсі користувача сценарії відображаються за допомогою таблиці (рис. 2).
У роботі [2, с. 154] описано підхід до генерації сценаріїв за допомогою графової бази даних 3 використанням у якості вершин графу подій, а у якості ребер взаємозв'язків. Характеристики сценарію згенерованого за методом, описаним у [2, с. 154], розраховуються за допомогою агрегатних функцій.

Визначення оптимального сценарію вимагає підключення модулю методів багатокритеріальної оптимізації. До складу цього модулю окрім реалізації математичної основи багатокритеріальної оптимізації має входити інтерфейс опису цільових функцій.

Реалізація інтерфейсу для запису цільових функцій можлива на основі предметно-орієнтованої мови програмування. Скоротити час створення предметно-орієнтованої мови можливо шляхом використання засобів автоматичної генерації аналізаторів [9, с. 2].

На першому кроці створення предметно-орієнтованої мови необхідний опис граматичних правил за допомогою форм Бекуса-Наура (далі БНФ) [10, с. 76]:

$<$ ОптимальністьЗаПарето $>::=<$ Функція $>\mid$

$<$ ОптимальністьЗаПарето $>$, <Функція >;

$<$ Функція $>::=<$ Оптимальність $>$

(«<НазваКритерію>»);

$<$ Оптимальність $>::=$ minimization| maximization»;

$<$ НазваКритерію $>::=[\mathrm{A}-\mathrm{Za}-\mathrm{Z0}-1]+$;

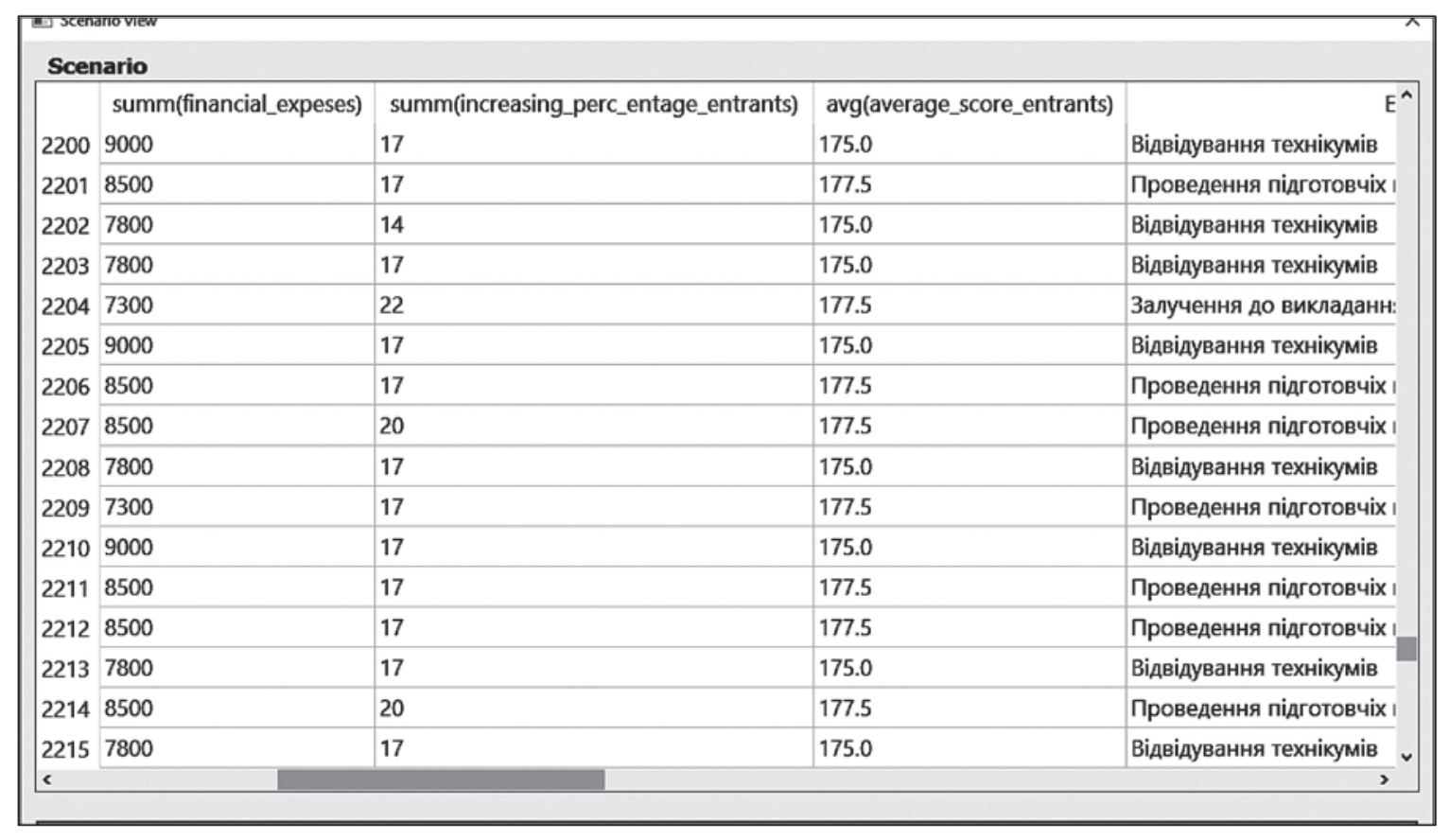

Рис. 2. Зображення множини згенерованих сценаріїв 
У $[9$, с. 2] досліджено, що для подібних мов оптимальним засобом генерації аналізаторів для предметно-орієнтованих мов $є$ Unicc. Цей інструмент дозволяє автоматичну генерацію лексичного та синтаксичного аналізаторів на основі опису граматик у вигляді БНФ. Основними перевагами інструменту є підтримка кирилиці та швидкодія розроблених аналізаторів [9, с. 2].

Визначити оптимальну за Парето альтернативу можна визначити задавши запит: minimization ("summ(actual hours)"), minimization ("summ(financial expeses)"), maximization("avg(average score entr)"), де характеристиками сценарію $€$ summ(actual_ hours) - сумарна кількість фактичних годин викладача витрачених на вступну кампанію, summ(financial_expeses) - сумарна кількість витрачених фінансів, avg(average_score entrants) - середній бал атестату абітурієнта, що братиме участь у подіях сценарію. Абстрактне синтаксичне дерево для цього запиту рображено на рис. 3.

Інший актуальний підхід до багатокритеріальної оптимізації - метод послідовних поступок. У основі методу послідовних поступок лежить ідея про те, що критерії мають різну важливість.

Використання методу послідовних вимагає впорядкування всіх критеріїв зростанням важливості:

$$
f_{1}\left(\mathrm{~g}_{\mathrm{i}}\right)>f_{3}\left(\mathrm{~g}_{\mathrm{i}}\right)>f_{3}\left(\mathrm{~g}_{\mathrm{i}}\right)>\ldots>f_{\mathrm{j}}\left(\mathrm{g}_{\mathrm{i}}\right),
$$

де $f_{\mathrm{j}}\left(\mathrm{g}_{\mathrm{i}}\right)-$ функція оптимальності $\mathrm{j}$-го критерію у i-тії альтернативі.

За алгоритмом на першому кроці необхідно знайти мінімальні або максимальні значення першого за важливість критерію в залежності від функції оптимізації. На наступному з утвореної на першому кроці множини альтернатив необхідно обрати оптимальні альтернативи за функцією оптимізації другого критерію і так далі.
Реалізація інтерфейсу для уведення функцій оптимізації та послідовності критеріїв можлива також за допомогою предметно-орієнтованої мови. У цьому випадку можливо застосувати аналізатори розроблені для попереднього методу.

Запит для визначення найбільш оптимально сценарію можна можливо у рядку такого вигляду: minimization ("summ(actual_hours)"), maximization("summ(Teachers hours according to the plan)"), minimization ("summ(financial exp eses)"), maximization("summ(increasing_perc entage entrants)"),maximization("avg(average score entrants)").

Обрати 3 множини згенерованих сценаріїв можливо застосувавши метод головного критерію. Алгоритм методу складається з таких кроків [11, c. 57]:

1) один змножини критеріїв $\mathrm{q}_{1}\left(\mathrm{~g}_{\mathrm{j}}\right), \mathrm{q}_{2}\left(\mathrm{~g}_{\mathrm{j}}\right), \mathrm{q}_{3}\left(\mathrm{~g}_{\mathrm{j}}\right) \ldots$ $\mathrm{q}_{\mathrm{j}}\left(\mathrm{g}_{\mathrm{i}}\right)$ визначається як головний, наприклад $\mathrm{q}_{1}\left(\mathrm{~g}_{\mathrm{i}}\right)$ сумарна кількість годин викладачів за планом, що будуть витрачені на вступну кампанію;

2) для всіх інших критеріїв $\mathrm{q}_{\mathrm{j}}\left(\mathrm{g}_{\mathrm{i}}\right)$ вводиться обмеження;

3) розв'язок однокритеріальної задачі, наприклад мінімізації:

3 обмеженнями:

$$
\mathrm{q}_{1}\left(\mathrm{~g}_{\mathrm{i}}\right) \rightarrow \min
$$

$$
\mathrm{q}_{1}\left(\mathrm{~g}_{\mathrm{i}}\right) \geq \mathrm{q}_{1}{ }^{0}, \mathrm{q}_{2}\left(\mathrm{~g}_{\mathrm{i}}\right) \geq \mathrm{q}_{2}{ }^{0}, \mathrm{q}_{3}\left(\mathrm{~g}_{\mathrm{i}}\right) \geq \mathrm{q}_{3}{ }^{\circ} \ldots \mathrm{q}_{\mathrm{j}}\left(\mathrm{g}_{\mathrm{i}}\right) \geq \mathrm{q}_{\mathrm{j}}{ }^{\circ}
$$

Реалізація методу головного критерію потребує створення окремого обробника виразів. За допомогою БНФ синтаксис обробника можливо представити таким чином:

$<$ ОписГоловногоКритерію $>$ :: $=<$ ФункціяОпти мізації >,<Обмеження>;

$<$ Обмеження $>::=<$ ОбмеженняДляКритерію $>\mid<$ Обмеження>, <ОбмеженняДляКритерію>;

$<$ ОбмеженняДляКритерію $>::=$ «<НазваКритерію>» $<$ Умова $><$ Нначення $>$;

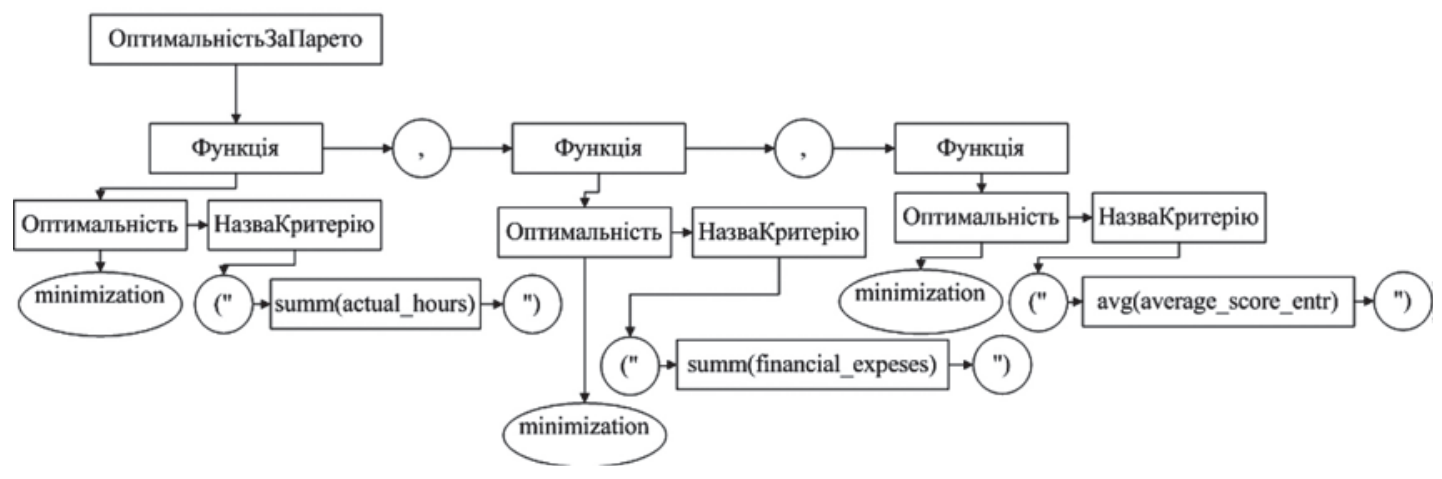

Рис. 3. Абстрактне синтаксичне дерево наведеного запиту 
$\langle$ Умова $>::=\langle\langle\rangle\rangle|\langle\langle>=\rangle|\langle=\rangle|\langle\langle!=\rangle|\langle\langle<=\rangle \mid\langle<\rangle\rangle ;$

$<$ Значення $>::=\wedge[0-9]+(\backslash .[0-9]\{1,2\})$ ?;

$<$ ФункціяОптимізації $>::=<$ Оптимальність $>$ (« $<$ НазваКритерію $>)\rangle$;

$<$ Оптимальність $>::=$

minimization| maximization;

$<$ НазваКритерію $>::=[\mathrm{A}-\mathrm{Za}-\mathrm{z} 0-1]+$;

Визначити оптимальні сценарії можливо ввівши запит такого вигляду: minimization("summ(actual hours)"). "summ(Teachers hours according to the

plan)" $>24$, "summ(financial_expeses)" $<9000$, де обмеженнями є: сумарна кількість годин викладача за планом - Teachers hours according to the plan, що має бути більше ніж 24 годин та вартість всіх подій сценарію - financial_expeses має бути менше ніж 9000, функцією оптимізації виступає мінімізація сумарна кількість фактичних годин викладачів витрачених на сценарій - summ(actual hours). Абстрактне синтаксичне дерево для цього запиту відображено на рис. 4.

Основою методу лінійної згортки $\epsilon$ встановлення коефіцієнтів важливості критеріям [7, с. 25]. Сума коефіцієнтів $\mu_{1}, \mu_{2}, \mu_{3}, \ldots, \mu_{\mathrm{n}}$ дорівнює одиниці, а функція домінування може бути представлена в такому вигляді $[12$, с. 75$]$ :

$$
\mathrm{Sce}^{*}>\mathrm{Sce}^{\prime} \Leftrightarrow \sum_{i=1 i}^{N} \mathrm{q}\left(g_{i}\right)^{*}>\sum_{i=1 i}^{N} \mathrm{q}\left(g_{i}\right)^{\prime}
$$

До результуючої множини включаються лише альтернативи, що мають максимальним значенням суми критеріїв з врахуванням коефіцієнтів:

$$
\mathrm{C}(\text { Sce }) \subset\left\{\operatorname{Sce}^{o} \in \operatorname{Sce} \mid \sum_{i=1}^{N} \mathrm{q}\left(g_{i}\right)^{o}=\max _{q(g) \in \operatorname{Sce}} \sum_{i=1}^{N} \mathrm{q}\left(g_{i}\right)\right\}
$$

Реалізація методу для інтеграції до інформаційної системи автоматичної генерації сценаріїв вимагає створення граматик для встановлення вагових коефіцієнтів. Синтаксичні правила можна представити у вигляді БНФ:

$<$ ЛінійнаЗгортка $>::=<$ КритерійЗкоефіцієнтом $>$ $\mid<$ ЛінійнаЗгортка $>,<$ КритерійЗкоефіцієнтоп>;

$<$ КритерійЗкоефіцієнтом $>::=<$ НазваКритерію $>:<$ Коефіцієнт $>$;

$<$ НазваКритерію $>::=[\mathrm{A}-\mathrm{Za}-\mathrm{z} 0-1]+$;

$<$ Коефіцієнт $>::=\wedge[0]$ (\.[0-9] $\{1,2\})$;

Для визначення оптимальності можливо застосувати запит такого вигляду: summ(actual_ hours):0.3, summ(Teachers_hours_according to_the_ plan):0.6, summ(financial_expeses):0.1; де сумарна кількість годин викладача за планом - Teachers_hours_according_to_the_plan, має коефіцієнт 0.6, вартість всіх подій сценарію financial expeses має коефіцієнт 0.1 та сумарна кількість фактичних годин викладачів витрачених на сценарій - summ(actual_hours) має коефiцієнт 0.3. Абстрактне синтаксичне дерево зображено на рис. 5.

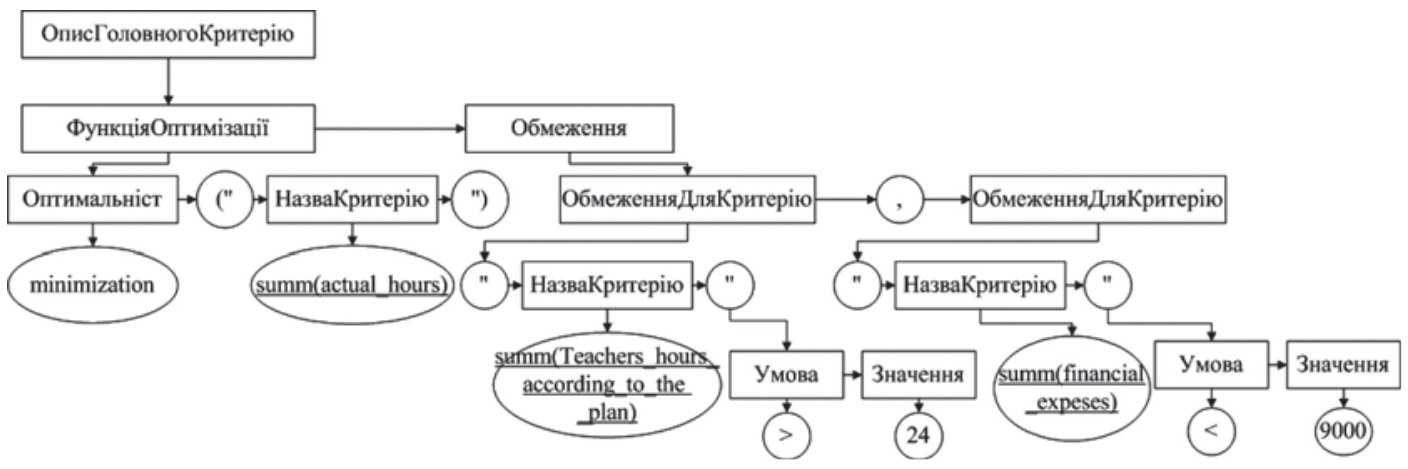

Рис. 4. Абстрактне синтаксичне дерево розбору для обробки методу головного критерію

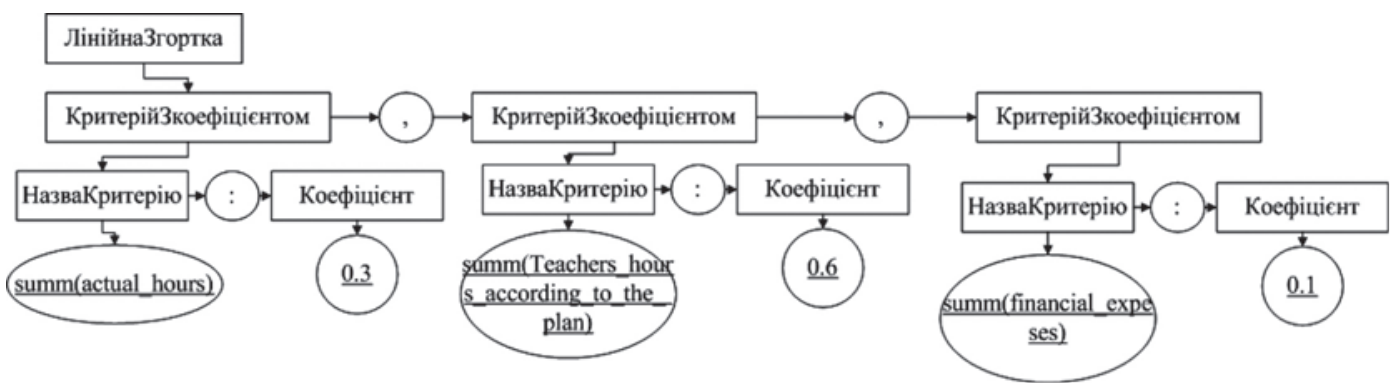

Рис. 5. Абстрактне синтаксичне дерево розбору для обробки методу лінійної згортки 


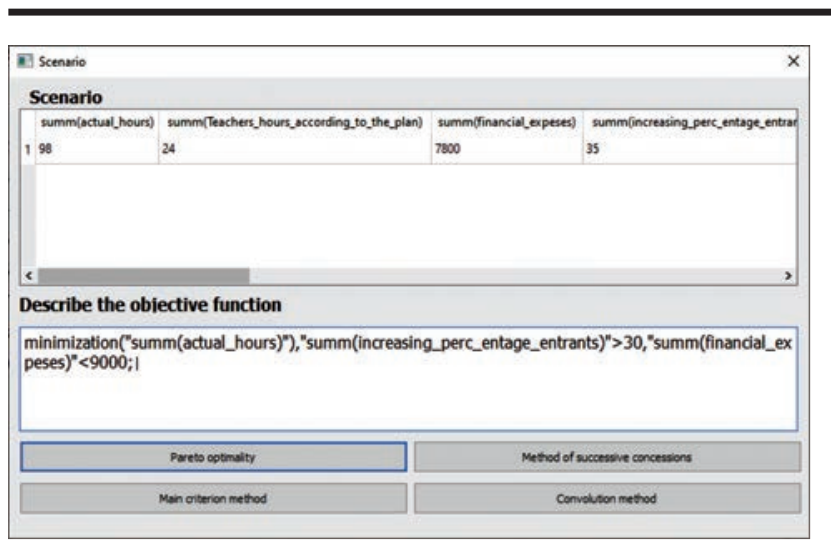

Рис. 6. Приклад застосування

методу головного критерію

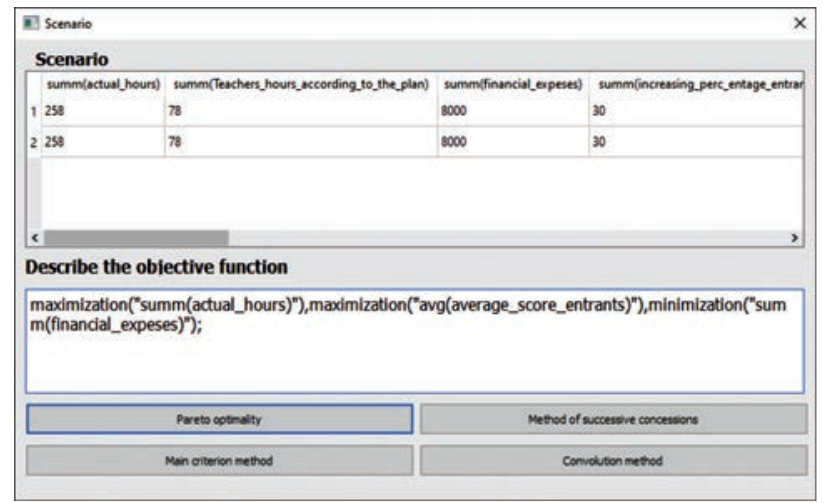

Рис. 7. Приклад застосування методу послідовних поступок
У задачах багатокритеріальної оптимізації популярним є MAI. Цей метод на відміну від попередніх вимагає наявності експертних висновків для порівняння альтернатив за певними критеріями та попарного порівняння експертами впливу альтернатив на головну мету [13, с. 126]. Факт наявності множини згенерованих сценаріїв (альтернатив) робить неможливим реалізацію попарного порівняння та недоцільним реалізацію методу для вибору оптимального сценарію.

Інтерфейс користувача для вибору методу оптимізації реалізовано на основі модулю PyQt [14]. Для введення запиту реалізовано поле textEdit, відображення оптимальних сценаріїв реалізовано за допомогою компоненту tableWidget. Кожен метод багатокритеріальної оптимізації працює при натисканні відповідної кнопки.

Проведено вибір оптимального сценарію 3 множини згенерованих, що частково представлена на рисунку 1 , з використанням методу головного критерію: головним критерієм визначено фактичну суму годин викладача, що має мінімізуватись, а у якості обмежень встановлено загальні фінансові витрати на сценарій в університеті, де працює автор (менш ніж 9000 грн), та загальну кількість абітурієнтів, що будуть зацікавлені спеціальністю внаслідок подій сценарію (більш ніж 30) (рис. 6).

Також застосовано метод послідовних поступок для відбору оптимальних сценаріїв при максимізації сумарної фактичної кількості годин викладача витрачених на вступну кампанію, максимізації середнього балу викладача та мінімізації фінансових витрати на реалізацію сценарію (рис. 7).

Висновки. Проведено аналіз методів багатокритеріальної оптимізації. Розроблено інформаційну систему для реалізації методів: лінійної згортки, послідовних поступок, головного критерію та оптимальності за Парето. Розроблено граматики для опису функцій оптимізації кожного методу багатокритеріальної оптимізації. Представлено інтерфейс користувача, що дозволяє ОПР застосувати один з реалізованих методів.

В подальшому планується інтеграція підсистеми обробника мови реляційної алгебри до розробленої системи для розширення можливостей маніпуляції множиною згенерованих сценаріїв та підмножиною оптимальних.

\section{Список літератури:}

1. Згуровський М.З. Сценарный анализ как системная методология предвидения. Систем. дослідж. та інформ. технології. 2002. № 1. С. 7-38.

2. Fisun M.T., Kandyba I.O., Borovlyova S.Y., Falenkova M.V. Development of software platforms for scenario generation using DSL and Neo4j graph database. SYSTEMY ZARZĄDZANIA I SPOŁECZNOGOSPODARCZE: NAUKOWE I PRAKTYCZNE ASPEKTY ZRÓWNOWAŻONEGO ROZWOJU ADMINISTRATIVE AND SOCIO-ECONOMIC SYSTEMS:SCIENTIFIC AND PRACTICAL ASPECTS OF SUSTAINABLE DEVELOPMENT : Monograph. Opole : The Academy of Management and Administration in Opole, 2021. P. $146-155$.

3. Гожий А.П., Коваленко И.И. Системные технологии генерации и анализа сценариев. Автоматика. Автоматизація. Електротехнічні комплекси та системи. 2005. № 2. С. 89-96.

4. Щурова 3.С., Жиров О.Л. Програмна реалізація задачі багатокритеріального вибору потенційного постачальника. Актуальні проблеми економіки та управління : збірник наукових праць молодих вчених. 2015. № 19. C. $568-575$. 
5. Задоров В.Б., Федусенко Е.В., Федусенко А.О. Застосування методів багатокритеріальної оптимізації до планування вантажних перевезень. Управління розвитком складних систем. Київський національний університет будівництва і архітектури. 2010. № 2. С. 27-30.

6. Марко М.Я., Цегелик Г.Г. Використання методу послідовних поступок для розв'язування задачі підвищення рентабельності виробництва малого підприємства. Наукові записки «Української академії друкарства». 2017. № 1. С. 141-146.

7. Леснік С.В., Хижняк Т.А Застосування методу лінійної згортки для вибору джерела альтернативної енергії. Електроніка та Зв’язок. 2013. Т. 18. № 3. С. 24-30.

8. Ногин В.Д. Множество и принцип Парето. Санкт-Петербург : Издательско-полиграфическая ассоциация высших учебных заведений, 2020. 100 с.

9. Використання методу аналізу ієрархій для вибору засобів розробки синтаксичних аналізаторів при створенні DSL / M.T. Фісун, I.О. Кандиба, Г.В. Горбань та ін. Наукові праці Вінницького національного технічного університету. 2021. № 1. URL: https://praci.vntu.edu.ua/index.php/praci/article/view/628.

10. Fowler M. Domain-Specific Languages. Boston : Addison-Wesley Professional, 2010. 640 p.

11. Файнзільберг Л.С., Жуковська О.А., Якимчук В.С. Теорія прийняття рішень. Київ : КПІ ім. Ігоря Сікорського, 2018. 246 с.

12. Ногин В.Д. Линейная свертка критериев в многокритериальной оптимизации. Искусственный интеллект и принятие решений. 2014. № 4. С. 73-82.

13. Методы системного анализа в задачах морских кластеров : монография / И.И. Коваленко, С.К. Чернов, А.В. Швед, Л.С. Чернова, Е.А. Антипова. Харьков : Новое слово, 2017. 268 с.

14. What is PyQt? Riverbank Computing : web-site. URL: https://www.riverbankcomputing.com/software/ pyqt/ (дата звернення: 12.07.2021).

\section{Kandyba I.O. MULTI-CRITERIA SELECTION OF THE BEST SCENARIO FOR A UNIVERSITY ENTRANCE CAMPAIGN}

The article gives an overview of modern multi-criteria optimization methods: Pareto optimality, method of successive concessions, main criterion method and linear convolution method. The possibility of implementing multicriteria optimization methods in a graph structure based scenario generation information system is investigated. Domain-specific language for description of target functions is proposed. The description of grammar for writing target functions in the application of Pareto optimality is given. The abstract syntactic trees of the given gramars are reflected. The lexical and syntactic parsers for processing of incoming string with description of optimality functions are created. An algorithm for finding Pareto set of optimal solutions from the set of generated scenarios is presented. The main principle and algorithm of realization of the method of successive concessions for selecting the best scenarios among the set of generated scenarios are described. The peculiarities of implementation of the main criterion method in an information system during generating a set of scenarios are presented. The grammar for processing incoming string containing optimization function and constraints of the main criterion method are given. The description of linear convolution method and implementation algorithm for information system of scenario generation based on graph structures are given. The syntax of grammar rules for the input string implementation of linear convolution method is proposed. A software implementation of all investigated multicriteria optimization methods is proposed. Description of the interface that allows a decision maker to choose one of the implemented methods of multicriteria optimization with the posibility of describing optimization functions and viewing optimal scenarios is given. The best scenarios for the admission campaign of the university based on the implemented methods of multicriteria optimization are selected.

Key words: multi-criteria optimization, successive concessions method, linear convolution method, main criterion method, Pareto optimality, domain-specific language. 